\title{
Basalt mine-tailings as raw-materials for Portland clinker
}

\section{(Rejeitos da mineração de basalto como matérias-primas para clínquer Portland)}

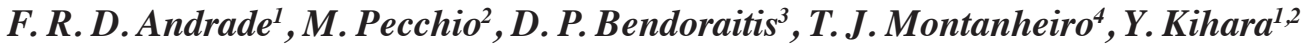 \\ ${ }^{1}$ Instituto de Geociências, Universidade de S. Paulo, Rua do Lago 562, S. Paulo, SP 05508-080 \\ ${ }^{2}$ Associação Brasileira de Cimento Portland, Av. Torres de Oliveira 76, S. Paulo, SP 05347-902 \\ ${ }^{3}$ Vale, CDM, Rodovia BR 381, km 450, Santa Luzia, MG 33040-900 \\ ${ }^{4}$ Instituto Geológico, Secretaria do Meio-Ambiente do Estado de S. Paulo, Av. Miguel Stéfano 3.900 \\ S. Paulo, SP 04301-903
}

\begin{abstract}
Large volumes of waste materials are produced by crushing of basaltic rocks for aggregate production, which is widely used in regions that lack rocks of granitic or gneissic composition. Two types of waste materials are produced (a) quarry fines, which are in part used as fine aggregates in concrete and (b) vesicular basalt, a porous variety of basalt that is useless as aggregate. This paper presents a procedure to use basaltic mine-tailings as raw-mixtures for Portland cement by adjusting the proportion of the other rawmaterials (limestone, clay, iron ore). It is demonstrated that there is no need for additional fluxes to the basalt-bearing raw-mixtures, since the setting of the chemical parameters is enough to guarantee clinker formation. Two series of experimental clinkers were synthesized with raw-mixtures containing residues from a basalt quarry that produces aggregates for concrete. Experimental clinkers were produced from raw-mixtures with similar lime saturation factors, silica and alumina modules, which were set by adjusting the proportions of limestone, clay and iron ore to the varying proportions of basaltic materials added to them. One series of clinkers was made with basalt quarry fines, which are in part used as fine aggregate, but also accumulate as mine-tailings. Other series was made using vesicular (porous) basalt, a variety not resistant enough to be used as aggregate. It is demonstrated that the basaltic composition is fully compatible with clinker production, and no addition of fluxes or other additions is required. Composition of the raw-mixtures was checked by chemical analysis. Quantitative phase analysis of the clinkers was made by optical microscopy point counting, together with qualitative X-ray diffraction. All mixtures produced clinkers with acceptable proportions of major and minor crystalline phases, inside the range of common industrial Portland clinkers.
\end{abstract}

Keywords: mine-tailings, basalt, Portland clinker.

\section{Resumo}

Duas séries de clínqueres experimentais foram sintetizadas com matérias-primas contendo rejeitos da mineração de basalto para a produção de agregados para concreto. Os clínqueres experimentais foram produzidos a partir de uma farinha crua padrão com adições de teores variáveis de materiais basálticos, sendo que o fator de saturação em cal e os módulos de sílica e alumina da farinha crua foram mantidos constantes pelo ajuste das proporções de calcário, argila e minério de ferro em relação ao teor de material basáltico adicionado. Uma das séries de clínqueres foi produzida com finos de pedreira, usados em parte como agregados finos, mas também acumulados como pilhas de rejeitos no pátio da mina. A outra série foi feita com basalto vesicular, uma variedade de basalto poroso e de baixa resistência,não aproveitada como agregado. Oestudo revela que a composição dos materiais basálticos éplenamente compatível com a produção de clínquer, não sendo necessária a adição de fundentes ou outros corretivos químicos. A composição dos clínqueres experimentais produzidos foi determinada por análises químicas, por análise quantitativa de fases em microscopia óptica (contagem de pontos) e por difratometria de raios X. Os clínqueres experimentais produzidos a partir de farinhas contendo materiais basálticos são similares aos clínqueres industriais convencionais, em termos de composição química e de proporção entre fases cristalinas. Palavras-chave: basalto, rejeitos de mineração, clínquer Portland

\section{INTRODUCTION}

Cofiring or coprocessing of wastes in the manufacturing of Portland cement is a practice of increasing importance, providing means to rationally use residues as substitutes for raw materials and fuels, and sparing primary resources $[e . g$. 1-3]. Portland cement is produced by heating up to $\sim 1450{ }^{\circ} \mathrm{C}$ in a rotating kiln a homogeneous mixture of raw-materials (limestone, clay, and minor amounts of iron ore and silica). Resulting pellets, known as clinker, are then milled with gypsum $\left(\mathrm{CaSO}_{4} .5 \mathrm{H}_{2} \mathrm{O}\right)$ to form the Portland cement.

Basalt is widely used as an aggregate for concrete, particularly in regions where quartz-feldspathic rocks are not available, and represents ca. $5 \%$ of the market for aggregates in Brazil [4]. Basalt quarries for aggregate production generate two types of large-scale residues: (a) quarry fines produced 
by crushing, which are in part used as fine aggregates in concrete; and (b) vesicular basalt, a porous variety of basalt that is useless as aggregate, and is therefore separated in the quarry bench. Basalt in southeastern Brazil belongs to the Cretaceous Serra Geral Formation (Paraná Basin), which crops out in an area of ca. 1,200,000 $\mathrm{km}^{2}$ and is the largest continental flood basalt volcanism worldwide, generated 130 Ma ago during the opening of the South Atlantic [8, 9]. According to the owner of the quarry sampled for this study, monthly aggregate production averages $40,000 \mathrm{~m}^{3}$, corresponding to 60,000 ton. By the time of the sampling (July, 2007), a $16 \mathrm{~m}$ thick layer of massive basalt was being mined, which was previously covered by a $9 \mathrm{~m}$ thick layer of vesicular basalt. Basaltic lava flows usually display a regular stratigraphy with an upper vesicular, porous layer. Vesicles are cavities formed when the upward migrating volcanic gases are trapped in the viscous lava, shortly before its full solidification. Vesicles may be either empty or filled with late-stage minerals, such as quartz, calcite and zeolites. Porosity significantly reduces resistance to compression, making vesicular basalt useless as aggregates. Quarry fines produced by crushing correspond to 18 to $20 \mathrm{wt}$ \% of the aggregate production. Part of this material is used as fine aggregate in concrete, as a substitute for natural sand, but its use is restricted because of the intrinsic angularity of the particles that lowers the workability of the concrete paste.

The aim of this paper is to present a simple procedure to use basaltic waste materials as raw-mixtures for Portland cement production, in which the input of basaltic materials in the raw-mixture is counterbalanced by changing the proportion of the other raw-materials (limestone, clay, iron ore).

\section{MATERIALS AND METHODS}

Ordinary Portland clinker is composed by the following crystalline phases: (i) $\mathrm{C}_{3} \mathrm{~S}\left(3 \mathrm{CaO} \cdot \mathrm{SiO}_{2}\right)$ also known as alite, is a major phase, and represents 40 to $70 \mathrm{wt} . \%$ of the clinker; (ii) $\mathrm{C}_{2} \mathrm{~S}\left(2 \mathrm{CaO} \mathrm{SiO}_{2}\right)$ also known as belite, is the second most important phase, averaging $20 \mathrm{wt} . \%$; (iii) $\mathrm{C}_{3} \mathrm{~A}(3 \mathrm{CaO}$. $\left.\mathrm{Al}_{2} \mathrm{O}_{3}\right)$ and $\mathrm{C}_{4} \mathrm{AF}\left(4 \mathrm{CaO} \cdot \mathrm{Al}_{2} \mathrm{O}_{3} \cdot \mathrm{Fe}_{2} \mathrm{O}_{3}\right)$ are interstitial phases that form a very fine-grained intergrowth matrix involving the major phases $\mathrm{C}_{3} \mathrm{~S}$ and $\mathrm{C}_{2} \mathrm{~S}$, comprising up to $10 \mathrm{wt} . \%$; (iv) free lime $(\mathrm{CaO})$ represents the excess lime that did not react with silica to form calcium silicates - it should be $<2$ wt. $\%$, because of its large heat of reaction and low contribution to the performance of the cement; (v) $\mathrm{MgO}$ is an inert compound that is formed if dolomitic limestones are used as raw-materials.

Chemical parameters of the raw-mixture indicate its capacity to form the above mentioned crystalline phases and are presented in Table I. The Lime Saturation Factor (LSF, industrial working range 90-100) is used to control $\mathrm{CaO}$ contents and avoid free lime formation. Silica module (SM, industrial working range 2.2-2.6) controls the relation between silicate phases $\left(\mathrm{C}_{3} \mathrm{~S}, \mathrm{C}_{2} \mathrm{~S}\right)$ and interstitial phases $\left(\mathrm{C}_{3} \mathrm{~A}, \mathrm{C}_{4} \mathrm{AF}\right)$, while the alumina module (AM, industrial
Table I - Chemical parameters of raw-mixtures for Portland clinker production [5]; all oxides in wt.\%.

[Tabela I - Parâmetros químicos da matéria-prima para produção de clínquer Portland [5]; todos os óxidos em \% peso.]

chemical parameters

$\begin{aligned} & \text { lime saturation } \\ & \text { factor }(L S F)\end{aligned} \quad \mathrm{LSF}=\frac{\mathrm{CaO}}{2.8 \times \mathrm{SiO}_{2}+1.2 \times \mathrm{Al}_{2} \mathrm{O}_{3}+0.65 \mathrm{Fe}_{2} \mathrm{O}_{3}}$

silica

module $(S M)$

$$
\mathrm{SM}=\frac{\mathrm{SiO}_{2}}{\mathrm{Al}_{2} \mathrm{O}_{3}+\mathrm{Fe}_{2} \mathrm{O}_{3}}
$$

alumina

module $(A M)$

$$
\mathrm{AM}=\frac{\mathrm{Al}_{2} \mathrm{O}_{3}}{\mathrm{Fe}_{2} \mathrm{O}_{3}}
$$

working range 1.4-2.0) is proportional to the viscosity of the liquid phase formed in the kiln.

Burnability measures the readiness of a raw-mixture to promote the reaction between lime and silica, keeping free lime in acceptable levels $[5,6]$. Burnability decreases with increasing LSF and SM, suggesting that lower fractions of liquid phase are formed in the process [7].

Experimental clinkers were produced with standard limestone, clay and iron ore, and basaltic waste materials (quarry fines, vesicular basalt) collected in a quarry in the central part of São Paulo State, southeastern Brazil.

Chemical composition of all raw-materials (Table II) was determined by complexometric titration and was used to calculate the chemical parameters $(L S F, S M, A M)$ of the raw-mixtures. A reference raw-mixture (limestone, clay, iron ore) was prepared without any basaltic addition. Minetailings were added to the raw-mixtures in amounts of 1,3 , 5,7 and $10 \mathrm{wt} . \%$ for both vesicular basalt and quarry fines. Chemical parameters were set by changing the proportions of limestone, clay and iron ore to counterbalance the input of basaltic materials. For each experimental clinker the proportion of limestone, clay, iron ore and basaltic materials was established by trial-and-error in a spreadsheet that contained the chemical composition of each raw-material and the equations for the chemical parameters - given the input of basaltic materials, the other raw-materials were mixed in order to keep the chemical parameters in the desired intervals. Lime saturation factor (LSF) was set in 91 - 92, silica module (SM) was set in $2.5-2.6$; and alumina module (AM) was set in 1.5 - 1.6. Two raw-mixtures were prepared with limestone and a maximum content of each basaltic material (vesicular basalt 17.9 wt.\%; quarry fines 16.6 wt. \%), both without clay and iron ore.

The experimental clinkers were made with the following procedure. All mixtures were made with 90 wt. $\%$ of the particles passing in the $\# 325$ sieve $(45 \mu \mathrm{m})$ and homogenized in air for $15 \mathrm{~min}$ in sealed plastic bags. After that, 20 wt. $\% \mathrm{H}_{2} \mathrm{O}$ was added to form $1.5 \mathrm{~cm}$ diameter pellets. The pellets were left at $100{ }^{\circ} \mathrm{C}$ for $24 \mathrm{~h}$, calcined 
Table II - Chemical composition of starting materials*.

[Tabela II - Composição química das matérias-primas*.]

\begin{tabular}{cccccc}
\hline & limestone & clay & iron ore & vesicular basalt & quarry fines \\
\hline $\mathrm{SiO}_{2}($ wt. \%) & 6.88 & 62.2 & 10.3 & 46.6 & 50.9 \\
$\mathrm{CaO}$ & 48.07 & 0.84 & 0.61 & 8.59 & 8.99 \\
$\mathrm{MgO}$ & 0.87 & 1.05 & 0.16 & 3.87 & 5.32 \\
$\mathrm{Fe}_{2} \mathrm{O}_{3}$ & 0.65 & 8.42 & 84.2 & 13.7 & 15.2 \\
$\mathrm{Al}_{2} \mathrm{O}_{3}$ & 1.32 & 17.8 & 2.02 & 11.3 & 12.5 \\
$\mathrm{Na}_{2} \mathrm{O}$ & n.d. & n.d. & n.d. & 3.81 & 3.51 \\
$\mathrm{~K}_{2} \mathrm{O}$ & n.d. & n.d. & n.d. & 0.83 & 0.81 \\
$\mathrm{TiO}_{2}$ & n.d. & n.d. & n.d. & 1.98 & 2.21 \\
total & 57.78 & 90.3 & 97.3 & 90.7 & 99.4 \\
$\mathrm{CaCO}_{3}$ (stoichiometric) & 85.76 & & & & \\
$\mathrm{MgCO}_{3}$ (stoichiometric) & 1.82 & & & & \\
total (recalculated) & 96.42 & & & &
\end{tabular}

*low totals refer to loss of ignition (LOI), not measured.

[*o baixo fechamento se refere à perda ao fogo (PF), não analisada.]

Table III - Raw-materials, chemical composition and chemical parameters of raw-mixtures, and $\mathrm{C}_{3} \mathrm{~S} / \mathrm{C}_{2} \mathrm{~S}$ ratio of respective clinkers.

[Tabela III - Matérias-primas, composição química e parâmetros químicos das farinhas cruas, e razões $C_{3} S / C_{2} S$ dos respectivos clínqueres.]

\begin{tabular}{|c|c|c|c|c|c|c|c|c|c|c|c|c|c|}
\hline & \multirow[b]{2}{*}{$\begin{array}{l}\text { reference } \\
\text { mixture }\end{array}$} & \multicolumn{6}{|c|}{ vesicular basalt } & \multicolumn{6}{|c|}{ basalt quarry fines } \\
\hline & & $\begin{array}{c}1 \mathrm{wt} . \\
\%\end{array}$ & $\begin{array}{c}3 \text { wt. } \\
\%\end{array}$ & $\begin{array}{c}5 \text { wt. } \\
\%\end{array}$ & $\begin{array}{c}7 \text { wt. } \\
\%\end{array}$ & $\begin{array}{c}10 \mathrm{wt} . \\
\%\end{array}$ & $\begin{array}{c}17.9 \mathrm{wt} . \\
\%\end{array}$ & $\begin{array}{c}1 \mathrm{wt} . \\
\%\end{array}$ & $\begin{array}{c}3 \mathrm{wt} . \\
\%\end{array}$ & $\begin{array}{c}5 \mathrm{wt} . \\
\%\end{array}$ & $\begin{array}{c}7 \text { wt. } \\
\%\end{array}$ & $\begin{array}{c}10 \mathrm{wt} . \\
\%\end{array}$ & $\begin{array}{c}16.6 \mathrm{wt} \\
\%\end{array}$ \\
\hline $\begin{array}{l}\text { limestone } \\
\text { (wt.\%) }\end{array}$ & 86.3 & 86 & 85.6 & 85.4 & 84.7 & 84 & 82.1 & 86.2 & 85.9 & 85.5 & 85.2 & 84.6 & 83.4 \\
\hline clay & 13.4 & 12.7 & 11.3 & 9.6 & 8.3 & 6 & 0 & 12.6 & 11.1 & 9.5 & 7.8 & 5.4 & 0 \\
\hline iron ore & 0.3 & 0.3 & 0.1 & 0 & 0 & 0 & 0 & 0.2 & 0 & 0 & 0 & 0 & 0 \\
\hline basalt & 0 & 1 & 3 & 5 & 7 & 10 & 17.9 & 1 & 3 & 5 & 7 & 10 & 16.6 \\
\hline $\begin{array}{c}\mathrm{SiO}_{2} \\
\text { (wt.\%) }\end{array}$ & 14.30 & 14.31 & 14.32 & 14.17 & 14.25 & 14.17 & 13.99 & 14.29 & 14.34 & 14.33 & 14.27 & 14.27 & 14.18 \\
\hline $\mathrm{CaO}$ & 41.60 & 41.54 & 41.50 & 41.56 & 41.39 & 41.29 & 41.00 & 41.63 & 41.66 & 41.63 & 41.65 & 41.61 & 41.58 \\
\hline $\mathrm{MgO}$ & 0.89 & 0.92 & 0.98 & 1.04 & 1.09 & 1.18 & 1.41 & 0.93 & 1.02 & 1.11 & 1.19 & 1.32 & 1.61 \\
\hline $\mathrm{Fe}_{2} \mathrm{O}_{3}$ & 1.94 & 2.02 & 2.00 & 2.05 & 2.21 & 2.42 & 2.98 & 1.94 & 1.95 & 2.11 & 2.27 & 2.52 & 3.06 \\
\hline $\mathrm{Al}_{2} \mathrm{O}_{3}$ & 3.53 & 3.51 & 3.48 & 3.40 & 3.39 & 3.31 & 3.11 & 3.51 & 3.48 & 3.44 & 3.39 & 3.33 & 3.18 \\
\hline $\begin{array}{c}\text { total } \\
\text { chemical } \\
\text { parameters }\end{array}$ & 62.26 & 62.30 & 62.29 & 62.22 & 62.32 & 62.36 & 62.49 & 62.31 & 62.45 & 62.63 & 62.78 & 63.05 & 63.61 \\
\hline LSF & 91.35 & 91.10 & 91.05 & 92.16 & 91.17 & 91.33 & 91.47 & 91.51 & 91.37 & 91.21 & 91.53 & 91.30 & 91.36 \\
\hline SM & 2.61 & 2.59 & 2.61 & 2.60 & 2.55 & 2.47 & 2.30 & 2.62 & 2.64 & 2.58 & 2.52 & 2.44 & 2.27 \\
\hline $\begin{array}{l}\text { AM } \\
\text { clinker } \\
\text { phase } \\
\text { relation }\end{array}$ & 1.82 & 1.74 & 1.74 & 1.66 & 1.53 & 1.37 & 1.04 & 1.81 & 1.79 & 1.63 & 1.49 & 1.32 & 1.04 \\
\hline $\mathrm{C}_{3} \mathrm{~S} / \mathrm{C}_{2} \mathrm{~S}$ & 1.47 & 1.43 & 1.26 & 1.58 & 1.43 & 1.15 & 1.78 & 1.61 & 2.07 & 1.58 & 2.97 & 2.49 & 2.63 \\
\hline
\end{tabular}

in platinum crucibles at $600{ }^{\circ} \mathrm{C}$ for $20 \mathrm{~min}$, at $1450^{\circ} \mathrm{C}$ for $30 \mathrm{~min}$ and air-quenched, and stored in a moisture-free container for further analysis. Quantitative phase analysis of clinker polished sections (etched with $\mathrm{HNO}_{3}$ ) was made by reflected light microscopy point counting (3x900 points each) and converted into wt.\% considering respective 
densities $\left(\mathrm{C}_{3} \mathrm{~S}=3.20 \mathrm{~g} / \mathrm{cm}^{3} ; \mathrm{C}_{2} \mathrm{~S}=3.28 \mathrm{~g} / \mathrm{cm}^{3} ; \mathrm{C}_{3} \mathrm{~A}\right.$ and $\left.\mathrm{C}_{4} \mathrm{AF} \sim 3.41 \mathrm{~g} / \mathrm{cm}^{3} ; \mathrm{CaO}=3.30 \mathrm{~g} / \mathrm{cm}^{3} ; \mathrm{MgO}=3.58 \mathrm{~g} / \mathrm{cm}^{3}\right)$. Free lime was also chemically determined with ethylene glycol titration.

Qualitative X-ray diffractometry was undertaken using a Rigaku RINT2000 diffractometer, Cuk-alpha radiation with $40 \mathrm{kV}$ and $20 \mathrm{~mA}$, in a $\theta: 2 \theta$ Bragg-Brentano geometry, and scanning from 3 to $60^{\circ}, 2^{\circ} / \mathrm{min}$.

\section{RESULTS AND DISCUSSION}

Raw-material proportions, chemical compositions of raw-mixtures, together with the chemical parameters of the resulting clinkers are given in Table III. The chemical composition of raw-materials did not allow keeping AM
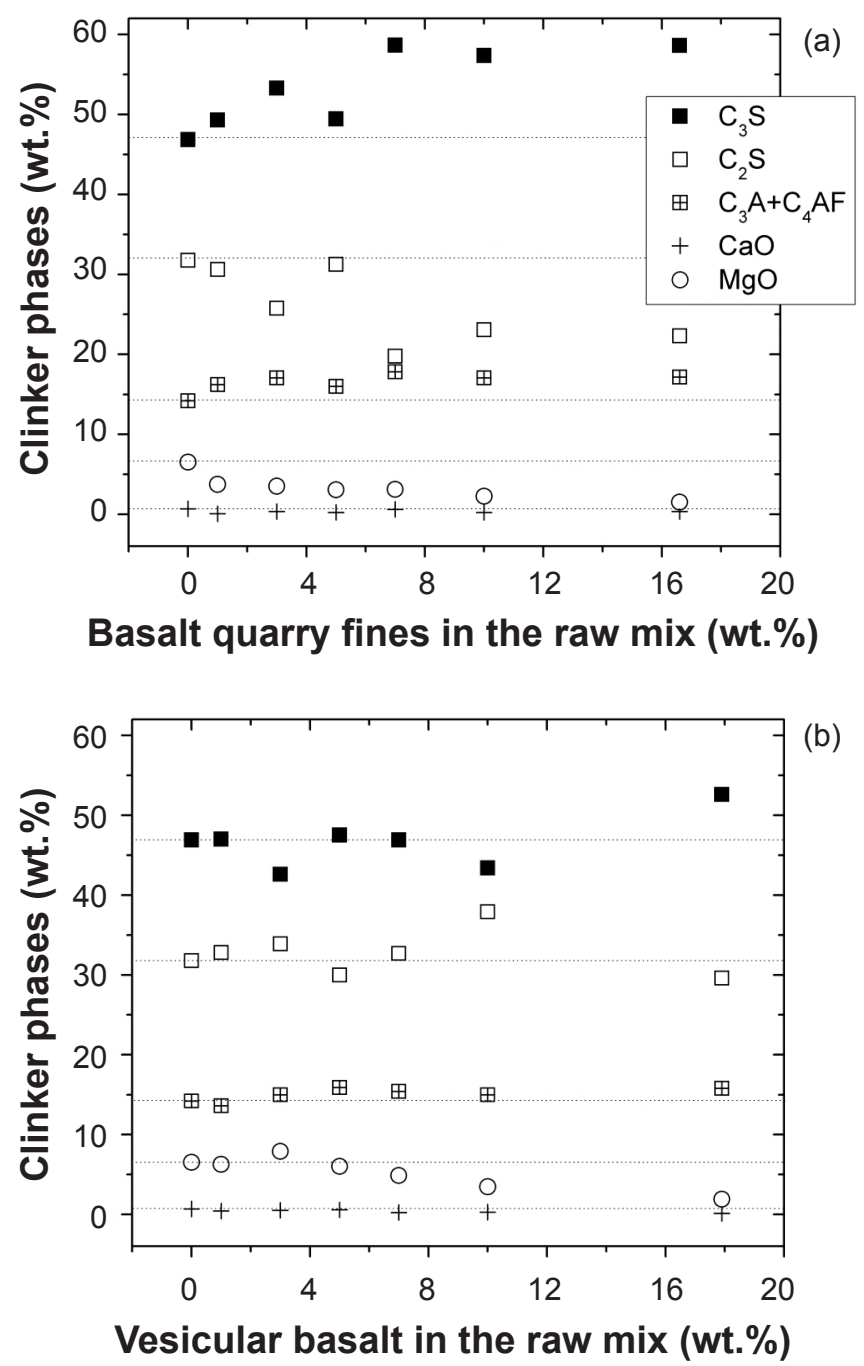

Figure 1: Relative abundance of crystalline phases in experimental clinkers with (a) basalt quarry fines and (b) vesicular basalt. Dashed lines represent values in the reference sample (without addition of basaltic materials).

[Figura 1: Abundância relativa de fases cristalinas em clínquers experimentais com (a) finos de pedra basáltica e (b) baslato vesicular. As linhas tracejadas representam valores na amostra referência (sem adição de materiais basálticos).] in the ideal interval, and therefore it drifted out, in order to preserve the values LSF and SM, which are more influential in the formation of crystalline phases.

Quantitative phase analysis of clinkers indicates an increase in $\mathrm{C}_{3} \mathrm{~S}$ (from 47 to $53 \mathrm{wt} . \%$ ) with increasing quarry fines in the raw mix (Fig. 1a), with corresponding decrease in $\left(\mathrm{C}_{2} \mathrm{~S}+\mathrm{CaO}\right)$. Abundance of $\left(\mathrm{C}_{3} \mathrm{~A}+\mathrm{C}_{4} \mathrm{AF}\right)$ slightly increased, while $\mathrm{MgO}$ remained stable with increasing basaltic quarry fines addition.

On the other hand, addition of vesicular basalt (Fig. 1b) caused a slightly different trend, in which relative abundance of the crystalline phases remains close to the values of the reference clinker.

Experimental clinkers of both series exhibit crystalline phases expected for common Portland clinkers, with similar phase proportion and microscopic features, although laboratory clinkers with quarry fines display slightly higher $\mathrm{C}_{3} \mathrm{~S} / \mathrm{C}_{2} \mathrm{~S}$ compared to those with vesicular basalt (Table III). Chemical determination of free lime indicates that burnability remained stable in raw-mixtures with both types of residues, close to the reference values. Microtextural features are similar in the two series, with $\mathrm{C}_{3} \mathrm{~S}$ hexagonal to sub-hexagonal, lacking evidence of corrosion, with average size around $30 \mu \mathrm{m}$, containing inclusions of $\mathrm{C}_{2} \mathrm{~S} . \mathrm{C}_{2} \mathrm{~S}$ is rounded, with average size about $16 \mu \mathrm{m}$, without corrosion, forming irregular, broad zones. Free lime appears in irregular aggregates, maximum size $150 \mu \mathrm{m}$. $\mathrm{MgO}$ is rare, forming rounded zones with maximum size of $60 \mu \mathrm{m}$. Iron ore content in the reference raw-mixture (basalt-free) is $0.3 \mathrm{wt} . \%$. It was fully substituted by basaltic additions of $\geq 3 \mathrm{wt} . \%$ quarry fines and $\geq 5 \mathrm{wt}$.\% of vesicular basalt. Clay was completely substituted in clinkers with extreme compositions, i.e., 16.6 wt.\% quarry fines or $17.9 \mathrm{wt} . \%$ vesicular basalt, which were made with limestone and basaltic materials only. A small reduction in limestone consumption was possible with increasing addition of basaltic materials.

\section{CONCLUSIONS}

Basalt has been recently recognized as an alternative raw-material for Portland cement $[10,11]$, particularly as a substitute for clay in regions where this resource is scarce. It was suggested that basalt may substitute for clay in a 1:1 proportion, with an adjustement in the composition of the raw-mixture by adding $1 \mathrm{wt} . \%$ iron ore and $1 \mathrm{wt} . \%$ quartz [10]. On the ternary $\mathrm{SiO}_{2}-\mathrm{CaO}-\mathrm{Al}_{2} \mathrm{O}_{3}$ phase diagram, clinker composition lies between the fields of basaltic materials and the $\mathrm{CaO}$ corner [11], indicating that a mixture of them would provide the necessary composition for clinker formation. Experimental clinkers were produced with basaltic materials together with calcium fluorine (fluorite, $\mathrm{CaF}_{2}$ ) in the raw-mixture [11], in order to lower temperature of clinker formation. The main finding of the present study is that basaltic waste materials can be incorporated in Portland clinker production, without any additional fluxes to the basalt-bearing raw-mixtures, since the setting of the chemical parameters is enough to guarantee the production 
of good quality clinker. Reduction of free lime in both series indicates increase in burnability with increasing basalt contents, confirming that basalts are suitable for clinker production. It can be further enhanced by the presence minor and trace elements that act as fluxes and mineralizers. Presence of volcanic glass would also facilitate the lowering of clinker formation temperature. This practice bears relevant environmental aspects by opening an alternative for management of mine-tailings, with respective conservation of primary resources. Moreover, as basalts have a $\mathrm{CaO}$ content of ca. $9 \mathrm{wt} . \%$, basalt addition of $10 \mathrm{wt} . \%$ allows a decrease of $2 \mathrm{wt} . \%$ of limestone in the raw mixture, reducing $\mathrm{CO}_{2}$ emissions accordingly. A regular clinker kiln produces 1,000 ton of clinker daily, corresponding to 1,600 ton of raw-mixture. Therefore, adding $10 \mathrm{wt} . \%$ basalt to it would represent a monthly potential consumption of 4,800 ton of basaltic mine-tailings, instead of primary raw-materials. This volume of basaltic waste materials can be provided by a single basalt quarry, given its continuous production of quarry fines, and the occasional removal of the vesicular layer for the opening of every new mining front.

\section{ACKNOWLEDGEMENTS}

This research was supported by FAPESP (Proc. 2003/06259-4), that also provided a grant to D.P.B. (2005/53884). Prof. G. Szabó is acknowledged for English review.

\section{REFERENCES}

[1] F. R. D. Andrade, V. Maringolo, Y. Kihara, Cement Concrete Res. 33 (2003) 63.

[2] M. A. Trezza, A. N. Scian, Cement Concrete Res. 35 (2005) 438.

[3] N. Saikia, S. Kato, T. Kojima, Waste Management 27 (2007) 1178.

[4] DNPM (Departamento Nacional de Produção Mineral) Anuário Mineral Brasileiro (2006)

http://www.dnpm.gov.br/assets/galeriaDocumento/ AMB2006/III_2006.pdf (accessed September 09, 2008).

[5] H. F. W. Taylor, Cement Chemistry, $2^{\text {nd }}$ Ed., Thomas Telford Ltd., London, UK (1997) 480 p.

[6] K. Theisen, World Cement 23 (1992) 17.

[7] N. H. Christensen, Cement Concrete Res. 9 (1979) 219.

[8] A. J. Melfi, E. M. Piccirillo, The Mesozoic flood volcanism of the Paraná Basin, $1^{\text {st }}$ Ed., IAG-USP, S. Paulo, Brazil (1988) 600 p.

[9] V. A. Janasi, F. A. Negri, T. J. Montanheiro, V. A. Freitas, B. C. Rocha, P. M. Reis, Rev. Bras. Geoci. 37 (2007) 162.

[10] M. Y. Hassaan, Mater. Lett. 50 (2001) 172.

[11] R. Sanjaasuren, T. Erdenebat, P. F. Rumyantsev, Proc. $12^{\text {th }}$ Int. Conf. Chem. Cement, Eds.: J. J. Beaudoin, J. M. Makar, L. Raki, Cement Association of Canada, Montreal, Canada, cd-rom (2007).

(Rec.05/02/2009, Rev. 27/05/2009, Ac. 06/06/2009) 